Prepared in cooperation with the U.S. Army Corps of Engineers and the Bureau of Reclamation

Preliminary Flood-Duration Frequency Estimates Using Naturalized Streamflow Records for the Willamette River Basin, Oregon

Open-File Report 2018-1020 



\section{Preliminary Flood-Duration Frequency Estimates Using Naturalized Streamflow Records for the Willamette River Basin, Oregon}

By Greg D. Lind and Adam J. Stonewall

Prepared in cooperation with the U.S. Army Corps of Engineers and the Bureau of Reclamation

Open-File Report 2018-1020

U.S. Department of the Interior

U.S. Geological Survey 


\section{U.S. Department of the Interior \\ RYAN K. ZINKE, Secretary}

\section{U.S. Geological Survey \\ William H. Werkheiser, Deputy Director \\ exercising the authority of the Director}

U.S. Geological Survey, Reston, Virginia: 2018

For more information on the USGS-the Federal source for science about the Earth, its natural and living resources, natural hazards, and the environment-visit https://www.usgs.gov/ or call 1-888-ASK-USGS (1-888-275-8747).

For an overview of USGS information products, including maps, imagery, and publications, visit https:/store.usgs.gov.

Any use of trade, firm, or product names is for descriptive purposes only and does not imply endorsement by the U.S. Government.

Although this information product, for the most part, is in the public domain, it also may contain copyrighted materials as noted in the text. Permission to reproduce copyrighted items must be secured from the copyright owner.

Suggested citation:

Lind, G.D., and Stonewall, A.J., 2018, Preliminary flood-duration frequency estimates using naturalized streamflow records for the Willamette River Basin, Oregon: U.S. Geological Survey Open-File Report 2018-1020, 17 p., https://doi.org/10.3133/ofr20181020.

ISSN 2331-1258 (online) 


\section{Contents}

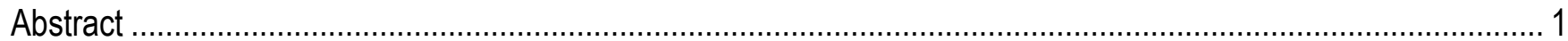

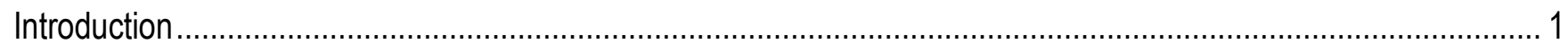

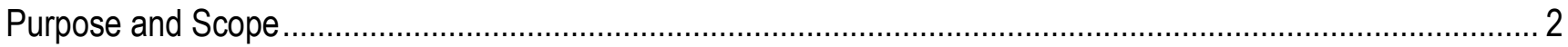

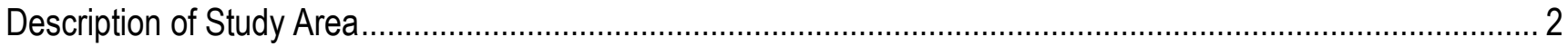

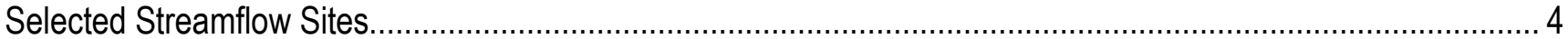

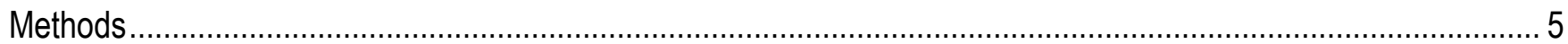

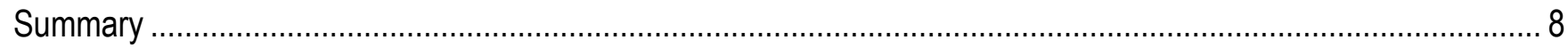

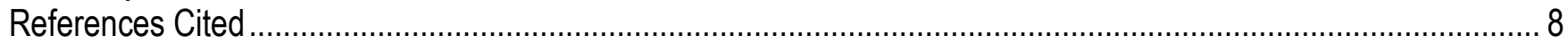

Figure

Figure 1. Map showing locations of 5 ecoregions and 26 selected streamflow sites in the

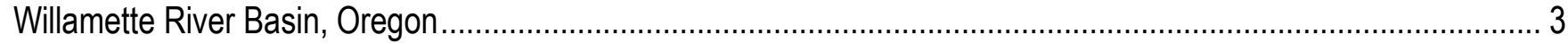

\section{Tables}

Table 1. Twenty-six selected streamflow sites in the Willamette River Basin, Oregon..................................... 5

Table 2. Flood-duration frequency estimates for sites in the Willamette River Basin, Oregon, for the 50-, 20-, 10-, 4-, 2-, 0.5-, and 0.2-percent annual exceedance probabilities..... 


\section{Conversion Factors}

U.S. customary units to International System of Units

\begin{tabular}{|c|c|c|}
\hline Multiply & By & To obtain \\
\hline \multicolumn{3}{|c|}{ Length } \\
\hline inch (in.) & 2.54 & centimeter $(\mathrm{cm})$ \\
\hline inch (in.) & 25.4 & millimeter $(\mathrm{mm})$ \\
\hline foot (ft) & 0.3048 & meter $(\mathrm{m})$ \\
\hline mile (mi) & 1.609 & kilometer $(\mathrm{km})$ \\
\hline \multicolumn{3}{|c|}{ Area } \\
\hline square mile $\left(\mathrm{mi}^{2}\right)$ & 2.590 & square kilometer $\left(\mathrm{km}^{2}\right)$ \\
\hline \multicolumn{3}{|c|}{ Volume } \\
\hline cubic foot $\left(\mathrm{ft}^{3}\right)$ & 0.02832 & cubic meter $\left(\mathrm{m}^{3}\right)$ \\
\hline \multicolumn{3}{|c|}{ Flow } \\
\hline cubic feet per second $\left(\mathrm{ft}^{3} / \mathrm{s}\right)$ & 0.0283 & cubic meter per second $\left(\mathrm{m}^{3} / \mathrm{s}\right)$ \\
\hline
\end{tabular}

\section{Datums}

Vertical coordinate information is referenced to the North American Vertical Datum of 1988 (NAVD 88).

Horizontal coordinate information is referenced to the North American Datum of 1983 (NAD 83).

Elevation, as used in this report, refers to distance above the vertical datum.

\section{Abbreviations}

$\begin{array}{ll}\text { USACE } & \text { U.S. Army Corps of Engineers } \\ \text { AEP } & \text { annual exceedance probability } \\ \text { Reclamation } & \text { Bureau of Reclamation } \\ \text { BPA } & \text { Bonneville Power Administration } \\ \text { EMA } & \text { Expected Moments Algorithm } \\ \text { MOVE } & \text { maintenance of variance extension } \\ \text { NRNI } & \text { no-regulation no-irrigation } \\ \text { NWIS } & \text { National Water Information System } \\ \text { PILF } & \text { potentially influential low flow } \\ \text { SREF } & \text { streamflow record extension facilitator } \\ \text { EPA } & \text { U.S. Environmental Protection Agency } \\ \text { USGS } & \text { U.S. Geological Survey }\end{array}$




\title{
Preliminary Flood-Duration Frequency Estimates Using Naturalized Streamflow Records for the Willamette River Basin, Oregon
}

By Greg D. Lind and Adam J. Stonewall

\begin{abstract}
In this study, "naturalized" daily streamflow records, created by the U.S. Army Corps of Engineers and the Bureau of Reclamation, were used to compute 1-, 3-, 7-, 10-, 15-, 30-, and 60-day annual maximum streamflow durations, which are running averages of daily streamflow for the number of days in each duration. Once the annual maximum durations were computed, the floodduration frequencies could be estimated. The estimated flood-duration frequencies correspond to the 50-, 20-, 10-, 4-, 2-, 1-, 0.5-, and 0.2-percent probabilities of their occurring or being exceeded each year. For this report, the focus was on the Willamette River Basin in Oregon, which is a subbasin of the Columbia River Basin. This study is part of a larger one encompassing the entire Columbia Basin.
\end{abstract}

\section{Introduction}

Flood-frequency estimates provide information used to design, maintain, and operate structures that convey or retain large volumes of streamflow. For structures such as bridges and culverts, the flood-frequency predictions of most interest are annual exceedance probabilities (AEP). An AEP (also known as the "annual peak-flow prediction") is the estimated probability that a certain instantaneous streamflow will be equaled or exceeded for any given year. A recurrence interval of 100 years, also known as a "100-year event," has an AEP of 1/100 (or 1 percent).

AEP of flood-durations is important to consider for public agencies or private companies operating water-retention structures such as dams and levees. Flood-durations are running averages of daily streamflow during selected time periods, usually described as "N-days" where " $\mathrm{N}$ " refers to the number of days contained by a particular duration. Flood-duration frequency estimates are required to effectively and safely operate dams and reservoirs, especially if their primary purpose is for flood control. 
Most Federal agencies involved with flood-frequency studies follow the guidelines of Bulletin 17B, which was issued by the Interagency Committee on Water Data, Hydrology Subcommittee (Interagency Advisory Committee on Water Data, 1982). The method recommended by Bulletin 17B to predict flood frequencies is fitting a log-Pearson type III (LP3) probability distribution to streamflow data. The data are logarithmically (base 10) transformed, which usually results in a more linear fit than plotting flood-flow data on an arithmetic scale using the original untransformed data. Fitting an LP3 distribution to streamflow data uses three sample moments: mean, standard deviation, and skew coefficient. Skew coefficients are a determinant of the shapes of the LP3 fitted curves, which can significantly affect the magnitudes of flood estimates.

\section{Purpose and Scope}

This report presents provisional, "naturalized" flood-duration frequencies corresponding to the 50-, 20-, 10-, 4-, 2-, 1-, 0.5-, and 0.2-percent probabilities of their occurring or being exceeded each year at 26 regulated stream sites in the Willamette River Basin. The Willamette River Basin analysis discussed in this report is part of a larger study, done in cooperation with the U.S. Army Corps of Engineers (USACE), that encompasses the entire Columbia River. One goal of the overall study is to estimate AEPs for 1-, 3-, 7-, 10-, 15-, 30-, and 60-day flood-duration frequencies, which will be used by the USACE to safely and effectively operate and maintain dams and reservoirs along the Columbia River system.

Another goal of the study is to develop 1-, 3-, 7-, 10-, 15-, 30-, and 60-day regional skew models for the Columbia River Basin. Currently, no N-day flood duration regional skew models have been developed for the entire basin. As recommended by Bulletin 17B, a regional skew is used to weight a station skew to make a particular site more representative of the region. Regional skew values can also be used to increase accuracies of flood-frequency predictions at ungaged locations within a basin. This would be valuable to public agencies and private companies that operate dams in areas where streamflow records do not exist.

\section{Description of Study Area}

The Willamette River Basin (fig. 1) is located in northwestern Oregon and has a drainage area of 11,500 $\mathrm{mi}^{2}$. The Coast Range bounds the basin on the west and the Cascade Range flanks the east; between these two mountain ranges lies the Willamette Valley. The Willamette River Basin includes parts of five ecoregions that are defined by a combination of geology, topography, climate, and other ecological considerations. These five ecoregions include Coast Range, Valley Foothills, Valley Plains, Western Cascades, and High Cascades (Omernik and Gallant, 1986; Clarke and others, 1991; Clarke and Bryce, 1997; Pater and others, 1998; Uhrich and Wentz, 1999; Watershed Professionals Network, 1999; Thiele and others, 2006). 


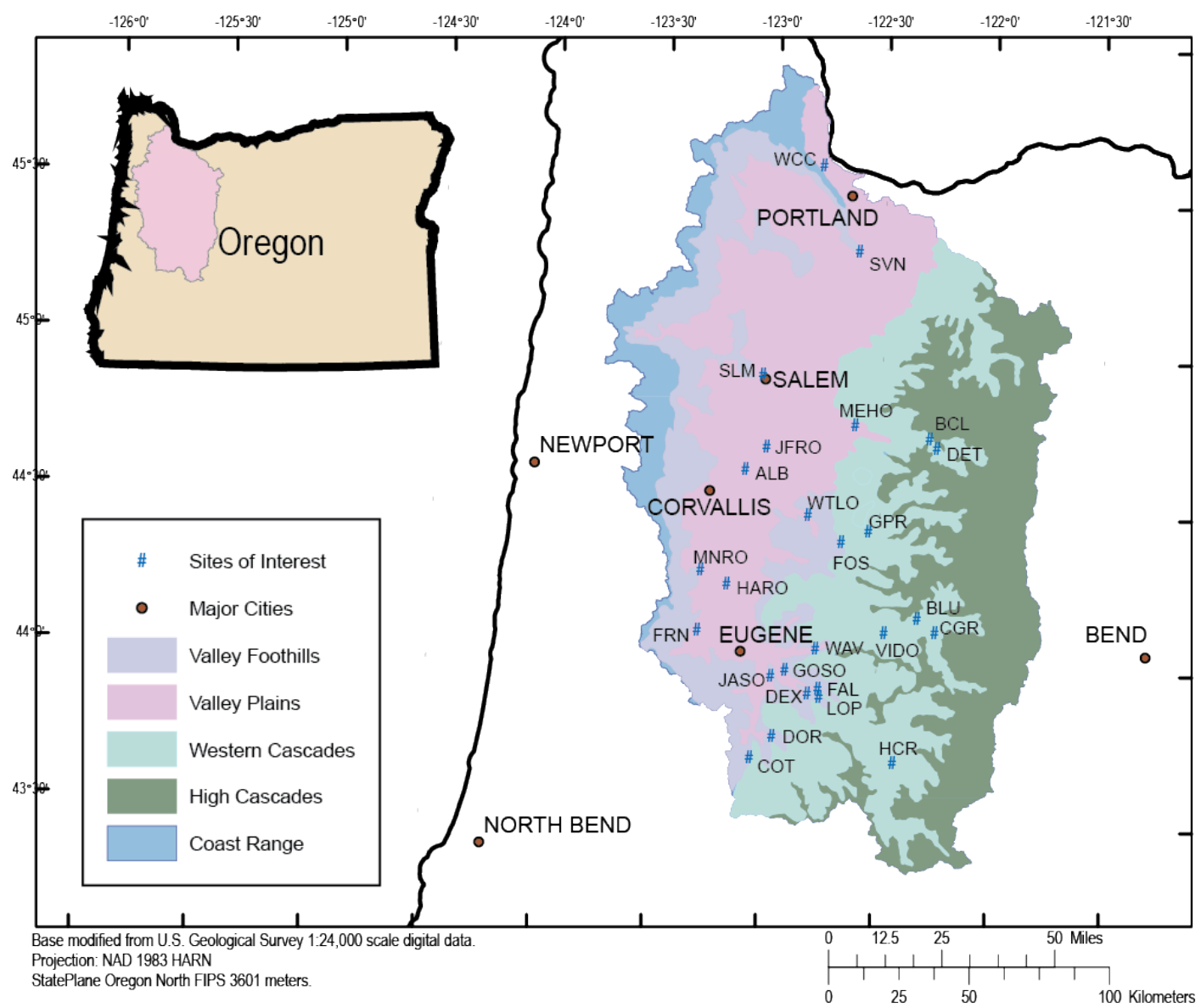

Figure 1. Map showing locations of 5 ecoregions and 26 selected streamflow sites in the Willamette River Basin, Oregon.

The Coast Range is made up of a combination of volcanic and sedimentary rock, the latter having two prominent forms, siltstone and sandstone (Pater and others, 1998). The topography is diverse, with steep slopes in the headwaters and more gradual gradients in lower lying areas.

Elevations usually range from 1,500 to $2,000 \mathrm{ft}$, with the highest elevations reaching $3,000 \mathrm{ft}$. The annual precipitation is from $70 \mathrm{in}$. in the lower elevations to $200 \mathrm{in}$. at the crest of the range, the majority falling in winter (Watershed Professionals Network, 1999; Miller, 2002). Rainstorms during the winter account for the highest sustained monthly flows and the largest peak flows during the year (Miller, 2002). 
The foothills surrounding the Willamette Valley are primarily composed of basalt and sandstone. Mostly comprising rolling hills, the slopes are moderate in the Valley Foothills. Elevations are typically in the range of 1,000-2,000 ft, with annual precipitations generally ranging from 40 to 60 inches, but up to 90 inches at higher elevations (Watershed Professionals Network, 1999; Miller, 2002). Like the Coastal Mountains, the majority of precipitation falls in winter months. Usually the highest sustained monthly flows take place in the winter, but snowmelt during the spring can also increase monthly flows. Winter storms with intense precipitation (often generated from atmospheric rivers) and rain-on-snow events are responsible for the largest peak flows.

The Valley Plains consist of fluvial deposits resulting from the ancient Missoula Floods, and much of the land is taken up by agriculture. Being in a lowland area, the valley has very little gradient or change in topology, with elevations ranging only from 100 to $300 \mathrm{ft}$. The annual precipitation is usually between 40 and 50 in., reaching up to 70 in. at higher elevations, with the majority falling in winter (Watershed Professionals Network, 1999; Miller, 2002). Winter rain produces the highest monthly flows and the largest peaks for streams with watersheds that are entirely encompassed within this region.

Volcanic rock and sediments make up the Western Cascades, which have elevations from 3,000 to $6,000 \mathrm{ft}$. Slopes are gradual in lower lying areas and steep in upper elevations. Annual precipitation generally ranges from 60 to $90 \mathrm{in}$. and can reach up to $110 \mathrm{in}$. in the highest elevations (Watershed Professionals Network, 1999; Miller, 2002). Most of the precipitation occurs during the winter. The highest sustained monthly flows take place during the spring snowmelt, and the largest peak flows occur in the winter from rain storms or rain-on-snow events.

The High Cascades comprise mostly lava flows and pyroclastic deposits along with some glacial deposits. Topographic gradients are moderate in the volcanic plateaus and steep in the upper elevations. The annual precipitation is typically in the range of 70-90 in. and up to $120 \mathrm{in}$. or more at higher elevations with most occurring in winter (Watershed Professionals Network, 1999; Miller, 2002). Spring snowmelt results in the highest sustained monthly streamflow whereas the largest peak flows in this subregion take place during the winter as a result of rain on snow events.

In 1996, heavy flooding occurred in the Willamette River Basin as a result of heavy rainfall and rapid snowmelt. It has been estimated that the damages caused by the floods of February 6-11, 1996, were reduced by 3.2 billion dollars through effective operations of flood control dams along the Columbia and Willamette River systems (American Institute of Hydrology, 1997).

\section{Selected Streamflow Sites}

For the purposes of this report, 26 streamflow sites of interest were selected for the Willamette River Basin (fig.1; table 1). Most of these sites are located at existing USACE reservoirs. Ten of these sites are located within the valley_nine are in the foothills, and the remaining seven are in the Western Cascade Mountains. Headwater sites are in locations that do not have upstream dams. Nine of the 26 sites are headwater sites, and 17 are sites downstream of one or more dams. 
Table 1. Twenty-six selected streamflow sites in the Willamette River Basin, Oregon.

[Site locations shown in figure 1. NRNI, no-regulation no-irrigation; USGS, U.S. Geological Survey]

\begin{tabular}{|c|c|c|c|}
\hline NRNI site ID & Stream & Location & $\begin{array}{c}\text { USGS } \\
\text { station No. }\end{array}$ \\
\hline ALB & Willamette River & Albany & 14174000 \\
\hline BCL & North Santiam River & Big Cliff Dam & 14181500 \\
\hline BLU & Blue River & Blue River Dam & 14162200 \\
\hline CGR & South Fork Mckenzie River & Cougar Dam & 14159500 \\
\hline $\mathrm{COT}$ & Coast Fork Willamette River & Cottage Grove Dam & 14153500 \\
\hline DET & North Santiam River & Detroit Dam & 14181500 \\
\hline DEX & Middle Fork Willamette River & Dexter Lake & 14150000 \\
\hline DOR & Row River & Dorena Dam & 14155500 \\
\hline FAL & Fall Creek & Fall Creek Dam & 14151000 \\
\hline FOS & South Santiam River & Foster Dam & 14187200 \\
\hline FRN & Long Tom River & Fern Ridge Dam & 14169000 \\
\hline GOSO & Coast Fork Willamette River & Goshen & 14157500 \\
\hline GPR & Middle Fork Santiam River & Green Peter Dam & 14186200 \\
\hline HARO & Willamette River & Harrisburg & 14166000 \\
\hline HCR & Middle Fork Willamette River & Hills Creek Dam & 14145500 \\
\hline JASO & Middle Fork Willamette River & Jasper & 14152000 \\
\hline JFRO & Santiam River & Jefferson & 14189000 \\
\hline LOP & Middle Fork Willamette River & Lookout Point Dam & 14150000 \\
\hline MEHO & North Santiam River & Mehama & 14183000 \\
\hline MNRO & Long Tom River & Monroe & 14170000 \\
\hline SLM & Willamette River & Salem & 14191000 \\
\hline SVN & Willamette River & T.W. Sullivan Power Plant & 14207740 \\
\hline VIDO & McKenzie River & Vida & 14162500 \\
\hline WAV & Mckenzie River & Walterville & 14163900 \\
\hline WCC & Willamette River & Columbia Confluence & 14211720 \\
\hline WTLO & South Santiam River & Waterloo & 14187500 \\
\hline
\end{tabular}

\section{Methods}

An important consideration for site selection in flood-frequency studies is whether or not the river or stream is affected by flow regulations. Heavily regulated streamflow results in a departure from the natural flow regime. A regulated stream may have truncated or attenuated streamflow peaks as a result of retaining water in an upstream reservoir during flood events, or conversely, during naturally occurring low periods the streamflow may be augmented by dam releases. Since a goal of flood-frequency studies is to predict natural streamflow events, the use of streamflow records from rivers or streams with regulated streamflow would violate the assumptions of flood frequency analysis. One way to handle this potential issue is to reconstruct the altered streamflow record to one that more closely represents the natural streamflow record, or the streamflow record that would exist if it were unregulated. 
All sites used in this study had regulation upstream. In order to account for this, the records were reconstructed in an attempt to remove regulatory effects, such as diversions or reservoir storage. The U.S. Army Corps of Engineers (ACOE), Bureau of Reclamation (Reclamation), and the Bonneville Power Administration (BPA) provided reconstructed, or naturalized, daily no-regulation no-irrigation (NRNI) streamflow records from 1928 to 2008 (Bonneville Power Administration, 2011; U.S. Army Corps of Engineers, 2014; K. Duffy, U.S. Army Corps of Engineers, written commun., 2017). The NRNI streamflow records are a modification of the 2010 Level Streamflow records (Bonneville Power Administration, 2011). Both datasets and their accompanying reports are available at https://www.bpa.gov/power/streamflow/default.aspx.

As a major objective of this study, the reconstructed NRNI streamflow records were reviewed and rated based on the quality of each record. If the source of data was a USGS streamgage, its accuracy was checked by comparing data downloaded from the National Water Information System (NWIS) (U.S. Geological Survey, 2016) for the streamgage corresponding with the NRNI streamflow data. Calculations made to datasets during the process of naturalizing the records were verified for accuracy using the equations provided by the USACE. Evaporation and water-use data from outside sources, such as the National Oceanic and Atmospheric Administration and the Oregon Water Resources Department, were used to compare with NRNI components for evaporation and depletion. As a check for consistency, NRNI datasets were plotted along with the measured datasets of regulated streamflow and visually inspected. After a record was reviewed, the quality of the streamflow data was determined. Records determined to be usable were given a rating of "excellent," "good," "fair," or "poor."

After the review was completed, it was decided that all 26 of the Willamette River Basin sites had usable records. All but four of these records had identical lengths of 80 years (July 1, 1928September 30, 2008). The remaining four sites, Jefferson, Harrisburg, Jasper, and Goshen, had 73 years of record (water years 1936-2008). Records were extended for the shorter periods by a USGS approved technique called the Maintenance of Variance Extension (MOVE) using the Streamflow Record Extension Facilitator (SREF version 1.0), a software package developed by the USGS (Granato, 2009). MOVE uses one or more longer records, from similar stations, to extend a shorter period of record at a station of interest. A correlation matrix was made using daily streamflow values from all 26 sites in the Willamette River Basin to determine which sites were the most similar to each other. The sites with longer records, which were found to have the highest correlations to the sites with shorter records, were used for the MOVE technique. SREF employs two versions of MOVE: type 1 (MOVE 1) and type 3 (MOVE 3). For high streamflow, which is the focus of this study, MOVE 1 is recommended over MOVE 3 (Granato, 2009). SREF was run for the four sites with shorter records and for each of the seven N-day flood durations, using both MOVE types. Based on the root mean-square error reported by the SREF output files, MOVE 1 performed better than MOVE 3 for all four sites receiving record extensions and for all seven N-day flood durations. It was decided to use MOVE 1 when extending the period of record for the four sites to 80 years.

Bulletin 17B recommends weighting station skews with a regional skew because the resultant weighted skews may be more accurate and representative of a particular basin, especially when records are short and of unequal length. Regional skews have been developed in various parts of the country based on hydrologically significant basin characteristics. Currently, no regional skew models for Nday flood duration frequencies have been developed for the Willamette River Basin. A sample size of 26 sites may be too small to accurately represent a basin as large and diverse as the Willamette River Basin. Bulletin 17B states that it may be reasonable to give more weight to station skews instead of weighting station skews with regional skew values if the stations being analyzed have relatively long record lengths. Since the records being used have identical lengths of 80 years (including the extended records), it was decided that using the station skews for these flood-duration frequency estimates without regional skew weighting would be adequate for this analysis. 
GW Toolbox is a USGS-developed software package that allows users the option to compute selected N-day flood durations after inputting a daily mean streamflow record (Barlow and others, 2014). The program will output the maximum selected N-day flood duration for each complete water year from the input record. Using the previously reviewed and approved naturalized daily streamflow records, furnished by the ACOE and the Reclamation, GW Toolbox was used to compute the N-day flood durations. An Excel ${ }^{\circledR}$ template was also created to compute the N-day flood durations as a check against the GW Toolbox output files. The two methods compared well.

There have been numerous recommendations for improvements to Bulletin 17B since it was published (Cohn and others, 1997, 2001; England and others, 2003; Griffis and others, 2004; Stedinger and Griffis, 2008). One potential area of improvement is in the treatment of low-flow outliers. Lowflow outliers are not the only low flows that can significantly affect the LP3 curve (Cohn and others, 2013). Any low flows, whether outliers or not, that extensively affect the LP3 curve are termed potentially influential low flows (PILFs). For this reason, the focus of flood frequency analysis has shifted from outliers to PILFs when considering which low flows should be of a concern.

Bulletin 17B recommends using the Grubbs-Beck test to treat PILFs. One of the shortfalls of the Grubbs-Beck test is that, when numerous PILFs exist, the test is limited in its ability to remove or treat all of them. The Multiple Grubbs-Beck test has been recommended as a more robust test in cases where multiple PILFs exist (Grubbs and Beck, 1972). If PILFs are not removed or properly adjusted for, they can significantly affect the LP3 fitted curve, especially at the upper end. Since flood frequency studies are concerned with high flows, PILFs must be treated correctly to avoid inaccurate high flow predictions.

Another suggested update to Bulletin 17B is the Expected Moments Algorithm (EMA) to fit the LP3 curve (Cohn and others 1997, 2001; Griffis and others, 2004). Bulletin 17B recommends using the method of moments when fitting a frequency curve to observed streamflow data. The EMA has been shown to provide a better fit for the LP3 curve when PILFs have been censored than the method of moments (Stedinger and Griffis, 2008). Another advantage of using the EMA is its ability to calculate the mean-square error of a station skew. The EMA and Multiple Grubbs-Beck test have been incorporated into Bulletin 17C, which will soon replace Bulletin 17B (England and others, in press).

PeakFQ (version 7.1) (Flynn and others, 2006), a USGS software package used to predict flood frequencies, was used for this report. The defaults for the PeakFQ program follow Bulletin 17B guidelines. However, PeakFQ allows users the option to use the Multiple Grubbs-Beck test in place of the Grubbs-Beck test. PeakFQ can also be run using the EMA option as opposed to the method of moments. It was decided to use PeakFQ using the Multiple Grubbs-Beck test and the EMA options for this analysis.

The sets of seven annual N-day flood durations generated by the GW Toolbox program were formatted so they could be run in the PeakFQ batch mode. The resulting LP3 fitted curves were visually inspected for reasonableness. The removal of outliers was visually inspected to determine whether they were treated in a reasonable manner. Sites with 25 percent or more of the streamflow record containing PILFs that were removed were visually inspected. Two sites had more PILFs censored from the streamflow records than the other sites. The Coast Fork Willamette River at Cottage Grove Dam, OR (USGS streamgage 14153599) site had 26 PILFs removed from the 1-day duration data set that was run through Peak FQ, which amounts to 30 percent of the total record. The other site, Coast Fork Willamette River at Goshen, OR (USGS streamgage 14157500), also had 30 percent of the PILFs removed from the set of 1-day durations. For both sites, all the other N-day flood durations had less than 30 percent of their original records removed after running PeakFQ. After visually inspecting these sites, the removal of PILFs seemed reasonable, and further adjustments were not necessary. 
When N-day flood duration AEPs are predicted, one area of concern is whether curve crossover occurs. For instance, curve crossover occurs when the predicted 7-day, 100-year flood is larger than the 3-day, 100-year flood estimate, which is unlikely statistically because shorter duration floods should be at least as high in magnitude as the longer duration floods. Usually, they will be higher. A similar concern exists for recurrence intervals, so that a 100 -year event should always be as large, or more often larger, than a 50-year event. All predicted N-duration floods were inspected for any crossovers. No crossovers were found for the predicted flood durations at any of the 26 sites, and no adjustments were deemed necessary. Tables of the estimated sets of N-day flood duration AEPs are shown in table 2 (at back of report).

\section{Summary}

Flood-duration frequency predictions provide valuable information used to safely and effectively operate and maintain dams and reservoirs. A major assumption of flood frequency analysis is that sites are unregulated. In this study, all selected sites had regulated streamflow. Reconstructed naturalized daily streamflow records, most of them provided by the USACE, were reviewed to determine if they were usable. Twenty-six naturalized daily streamflow records, all 73 or more years, were used for this study.

Four of the 26 daily streamflow records were extended, using the MOVE 1 method, resulting in all 26 records having the same length of 80 years. Bulletin 17B recommends using an estimated regional skew with the computed station skew which should result in a more representative weighted skew. However, because all the records used in this study had the same length of 80 years it was decided to use the individual station skews for this analysis.

The desired N-day flood durations were computed from the naturalized streamflow records using the USGS GW Toolbox software. The annual exceedance probabilities (AEPs) and three moments of the LP3 distribution where determined using the USGS PeakFQ software. PeakFQ was run using the Multiple Grubbs-Beck test and the Expected Moments Algorithm options.

The 1-, 3-, 7-, 10-, 15-, 30-, and 60-day flood durations are presented at AEP intervals coinciding with the 2-, 5-, 10-, 25-, 50-, 100-, 200-, and 500-year events or the 50-, 20-, 10-, 4-, 2-, 1-, $0.5-$, and 0.2 -percent probabilities, respectively. These flood predictions are provided on a preliminary basis because this study is part of a larger study encompassing the entire Columbia River Basin. With future analyses planned for both the Willamette and Columbia River Basins, revisions to these predictions may be warranted as further information is gained during the progression of this study.

\section{References Cited}

American Institute of Hydrology, 1997, The Pacific Northwest floods of February 6-11, 1996Proceedings of the Pacific Northwest Water Issues Conference October 78, 1997: Oregon Water Resources Research Institute, $317 \mathrm{p}$.

Barlow, P.M., Cunningham, W.L., Zhai, Tong, and Gray, Mark, 2014, U.S. Geological Survey Groundwater toolbox, a graphical and mapping interface for analysis of hydrologic data (version 1.0) - User guide for estimation of base flow, runoff, and groundwater recharge from streamflow data: U.S. Geological Survey Techniques and Methods, book 3, chap. B10, 27 p., http://dx.doi.org/10.3133/tm3B10.

Bonneville Power Administration, 2011, 2010 Level modified streamflow 1928-2008: Bonneville Portland, Oregon, Power Administration DOE/BP-4352, 581 p. 
Clarke, S.E., White, D., and Schaedel, A.L., 1991, Oregon, USA, ecological regions and subregions for water quality management: Environmental Management, v. 15, no. 6, p. 847-856.

Clarke, S.E., and Bryce, S.A., 1997, Hierarchical subdivisions of the Columbia Plateau and Blue Mountains ecoregions, Oregon and Washington: U.S. Forest Service, General Technical Report PNW-GTR-395, $114 \mathrm{p}$.

Cohn, T.A., Lane, W.L., and Baier, W.G., 1997, An algorithim for computing moments-based flood quantile estimates when historical flood information is available: Water Resources Research, v. 33, no. 9, p. 2,089-2,096.

Cohn, T.A., Lane, W.L., and Stedinger, J.R., 2001, Confidence intervals for Expected Moments Algorithm flood quantile estimates: Water Resources Research, v. 37, no. 6, p. 1,695-1,706.

Cohn, T.A., England, J.F., Barenbrock, C.E., Mason, R.R., Stedinger, J.R., and Lamontagne, J.R., 2013, A generalized Grubbs-Beck Test statistic for detecting multiple potentially-influential low outliers in flood series: Water Resources Research, v. 49, p. 1-12.

England, J.F., Jr., Salas, J.D., and Jarret, R.D., 2003, Comparisons of two moments-based estimators that utilize historical and paleoflood data for the log Pearson type III distribution: Water Resources Research, v. 39, no. 9, p. 1,243.

England, J.F., Jr., Cohn, T.A., Faber, B.A., Stedinger, J.R., Wilbert O.T., Veilleux, A.G., Kiang, J.E., and Mason, R.R., in press, Guidelines for determining flood flow frequency-Bulletin 17C: U.S. Geological Survey Techniques and Methods, book 4, chap. B5.

Flynn, K.M., Kirby, W.H., and Hummel, P.R., 2006, User manual for PeakFQ, annual flood frequency analysis using Bulletin 17B Guidelines: U.S. Geological Survey Techniques and Methods, book 4, chap. B4, 42 p.

Granato, G.E., 2009, Computer programs for obtaining and analyzing daily mean streamflow data from the U.S. Geological Survey National Water Information System Web Site: U.S. Geological Survey Open-File Report 2008-1362, 123 p.

Griffis, V.W., Stedinger, J.R., and Cohn, T.A., 2004, Log Pearson type 3 quantile estimators with regional skew information and low outlier adjustments: Water Resources Research, v. 40, no. 10, W07503.

Grubbs, F.E., and Beck, Glenn, 1972, Extension of sample sizes and percentage points for significance tests of outlying observations: Technometrics, v. 14, no. 4, p. 847-854.

Interagency Advisory Committee on Water Data, 1982, Guidelines for determining flood-flow frequency: Office of Water Data Coordination, U.S. Geological Survey, Bulletin \#17B of the Hydrology Subcommittee, 183 p.

Miller, G.R., 2002, Pacific Northwest weather-But my barometer says fair!-A look at those changing and peculiar weather patterns in the Pacific Northwest, large and small: Portland, Oregon, Frank Amato Publications, Inc., 174 p.

Omernik, J.M., and Gallant, A.L., 1986, Ecoregions of the Pacific Northwest: United States Environmental Protection Agency, EPA/600/3-86/033.

Pater, D.E., Bryce, S.A., Thorson, T.D., Kagan, J.C, Omernik, J., Azevedo, S.H., and Woods, A.J., 1998, Ecoregions of western Washington and Oregon: U.S Geological Survey, eMap. 
Stedinger, J.R., and Griffis, V.W., 2008, Flood frequency analysis in the United States-Time to update: Journal of Hydrologic Engineering, v. 13, p. 199-204.

Thiele, S., Pater, D.E., Thorson, T.D., Kagan, J.C, and Omernik, J., 2006, Level III and IV ecoregions of Oregon and Washington: United States Environmental Protection Agency and other state and federal cooperators.

Uhrich, M.A., and Wentz, D.A., 1999, Environmental setting of the Willamette Basin, Oregon: U.S Geological Survey Water-Resources Investigations Report 97-4082-A, 20 p. [Also available at https://pubs.er.usgs.gov/publication/wri974082A.]

U.S. Army Corps of Engineers, 2014, NRNI flows - Columbia River Basin development of NRNI Flows using 2010 modified flow results: U.S. Army Corps of Engineers, 12 p.

U.S. Geological Survey, 2016, National Water Information System: U.S. Geological Survey database, accessed July 13, 2016, at http://waterdata.usgs.gov/nwis/.

Watershed Professionals Network, 1999, Oregon watershed assessment manual: Governor's Watershed Enhancement Board, accessed September 5, 2017, at http://www.oregon.gov/OWEB/pages/publications.aspx. 
Table 2. Flood-duration frequency estimates for sites in the Willamette River Basin, Oregon, for the 50-, 20-, 10-, 4-, 2-, 0.5-, and 0.2-percent annual exceedance probabilities.

[NRNI Site ID, no-regulation no-irrigation site identification]

\begin{tabular}{|c|c|c|c|c|c|c|c|c|}
\hline \multicolumn{9}{|c|}{$\begin{array}{l}\text { Percent annual exceedance probability of 1-day flood-duration streamflow } \\
\text { (cubic feet per second) }\end{array}$} \\
\hline NRNI Site ID & 50 -percent & 20-percent & 10-percent & 4-percent & 2-percent & 1-percent & 0.5 -percent & 0.2-percent \\
\hline ALB & 100,000 & 147,000 & 176,000 & 212,000 & 237,000 & 261,000 & 284,000 & 314,000 \\
\hline BCL & 17,300 & 25,000 & 30,000 & 37,100 & 42,400 & 47,800 & 53,300 & 60,800 \\
\hline BLU & 5,240 & 7,650 & 9,390 & 11,700 & 13,600 & 15,500 & 17,500 & 20,400 \\
\hline CGR & 6,320 & 9,530 & 11,800 & 14,700 & 17,000 & 19,300 & 21,600 & 24,800 \\
\hline COT & 3,220 & 4,950 & 5,970 & 7,120 & 7,860 & 8,530 & 9,130 & 9,830 \\
\hline DET & 17,300 & 25,000 & 30,300 & 37,100 & 42,400 & 47,800 & 53,300 & 60,800 \\
\hline DEX & 24,700 & 37,700 & 46,500 & 57,600 & 65,900 & 74,100 & 82,200 & 93,000 \\
\hline DOR & 9,140 & 13,600 & 16,300 & 19,700 & 22,000 & 24,200 & 26,200 & 28,900 \\
\hline FAL & 6,570 & 9,410 & 11,200 & 13,300 & 14,800 & 16,300 & 17,600 & 19,400 \\
\hline FOS & 26,800 & 38,300 & 46,700 & 58,200 & 67,400 & 77,200 & 87,600 & 103,000 \\
\hline FRN & 6,600 & 10,700 & 13,600 & 17,400 & 20,200 & 23,100 & 26,000 & 29,900 \\
\hline GOSO & 18,300 & 30,000 & 36,600 & 43,500 & 47,800 & 51,300 & 54,200 & 57,400 \\
\hline GPR & 17,200 & 24,600 & 29,900 & 37,300 & 43,200 & 49,500 & 56,200 & 65,800 \\
\hline HARO & 91,000 & 134,000 & 161,000 & 193,000 & 215,000 & 236,000 & 256,000 & 281,000 \\
\hline HCR & 9,510 & 15,000 & 18,800 & 23,900 & 27,800 & 31,700 & 35,800 & 41,300 \\
\hline JASO & 34,900 & 52,400 & 64,300 & 79,600 & 91,100 & 103,000 & 114,000 & 130,000 \\
\hline JFRO & 73,200 & 105,000 & 129,000 & 162,000 & 190,000 & 219,000 & 251,000 & 298,000 \\
\hline LOP & 24,700 & 37,700 & 46,500 & 57,600 & 65,900 & 74,100 & 82,200 & 93,000 \\
\hline MEHO & 29,200 & 42,400 & 51,600 & 63,900 & 73,400 & 83,300 & 93,600 & 108,000 \\
\hline MNRO & 9,850 & 15,700 & 19,600 & 24,600 & 28,200 & 31,700 & 35,200 & 39,700 \\
\hline SLM & 156,000 & 223,000 & 268,000 & 326,000 & 370,000 & 415,000 & 460,000 & 522,000 \\
\hline SVN & 201,000 & 281,000 & 336,000 & 409,000 & 465,000 & 523,000 & 583,000 & 666,000 \\
\hline VIDO & 23,500 & 33,600 & 40,400 & 48,900 & 55,200 & 61,400 & 67,700 & 76,000 \\
\hline WAV & 26,800 & 38,100 & 45,700 & 55,200 & 62,200 & 69,300 & 76,400 & 85,900 \\
\hline WCC & 225,000 & 314,000 & 376,000 & 458,000 & 521,000 & 585,000 & 653,000 & 746,000 \\
\hline WTLO & 29,900 & 42,600 & 51,200 & 62,500 & 71,000 & 79,700 & 88,600 & 101,000 \\
\hline
\end{tabular}




\begin{tabular}{|c|c|c|c|c|c|c|c|c|}
\hline \multicolumn{9}{|c|}{$\begin{array}{l}\text { Percent annual exceedance probability of 3-day flood-duration streamflow } \\
\text { (cubic feet per second) }\end{array}$} \\
\hline NRNI Site ID & 50-percent & 20-percent & 10-percent & 4-percent & 2-percent & 1-percent & 0.5 -percent & 0.2 -percent \\
\hline ALB & 88,500 & 127,000 & 153,000 & 185,000 & 208,000 & 231,000 & 254,000 & 284,000 \\
\hline BCL & 13,200 & 19,100 & 23,200 & 28,600 & 32,700 & 36,900 & 41,100 & 47,000 \\
\hline BLU & 3,900 & 5,590 & 6,730 & 8,190 & 9,280 & 10,400 & 11,500 & 13,000 \\
\hline CGR & 4,840 & 7,240 & 9,030 & 11,500 & 13,500 & 15,700 & 18,000 & 21,400 \\
\hline COT & 2,380 & 3,460 & 4,150 & 4,990 & 5,580 & 6,150 & 6,700 & 7,400 \\
\hline DET & 13,200 & 19,100 & 23,200 & 28,600 & 32,700 & 36,900 & 41,100 & 47,000 \\
\hline DEX & 18,400 & 27,600 & 34,200 & 43,100 & 50,000 & 57,200 & 64,800 & 75,400 \\
\hline DOR & 6,550 & 9,490 & 11,400 & 13,600 & 15,200 & 16,700 & 18,200 & 20,100 \\
\hline FAL & 4,770 & 6,660 & 7,860 & 9,300 & 10,300 & 11,300 & 12,300 & 13,500 \\
\hline FOS & 20,100 & 28,500 & 34,000 & 40,800 & 45,700 & 50,600 & 55,500 & 61,900 \\
\hline FRN & 5,560 & 8,560 & 10,500 & 13,000 & 14,700 & 16,400 & 18,100 & 20,200 \\
\hline GOSO & 14,200 & 20,700 & 25,000 & 30,200 & 34,000 & 37,600 & 41,200 & 45,900 \\
\hline GPR & 12,700 & 18,100 & 21,700 & 26,300 & 29,800 & 33,200 & 36,700 & 41,300 \\
\hline HARO & 70,000 & 102,000 & 122,000 & 146,000 & 164,000 & 180,000 & 196,000 & 217,000 \\
\hline $\mathrm{HCR}$ & 6,980 & 10,800 & 13,600 & 17,500 & 20,600 & 23,900 & 27,400 & 32,400 \\
\hline JASO & 26,200 & 38,600 & 47,500 & 59,500 & 69,000 & 79,000 & 89,400 & 104,000 \\
\hline JFRO & 55,700 & 79,500 & 95,500 & 116,000 & 131,000 & 146,000 & 161,000 & 182,000 \\
\hline LOP & 18,400 & 27,600 & 34,200 & 43,100 & 50,000 & 57,200 & 64,800 & 75,400 \\
\hline MEHO & 21,900 & 31,400 & 37,700 & 45,900 & 52,000 & 58,200 & 64,400 & 72,800 \\
\hline MNRO & 8,170 & 12,500 & 15,300 & 18,600 & 20,900 & 23,200 & 25,300 & 28,000 \\
\hline SLM & 144,000 & 202,000 & 241,000 & 290,000 & 326,000 & 363,000 & 400,000 & 450,000 \\
\hline SVN & 188,000 & 261,000 & 311,000 & 377,000 & 427,000 & 479,000 & 533,000 & 607,000 \\
\hline VIDO & 18,400 & 26,300 & 31,900 & 39,100 & 44,700 & 50,400 & 56,300 & 64,400 \\
\hline WAV & 21,400 & 30,200 & 36,300 & 44,000 & 49,800 & 55,800 & 61,800 & 70,100 \\
\hline WCC & 211,000 & 292,000 & 349,000 & 422,000 & 479,000 & 537,000 & 597,000 & 680,000 \\
\hline WTLO & 22,400 & 31,500 & 37,500 & 45,000 & 50,500 & 56,000 & 61,400 & 68,600 \\
\hline
\end{tabular}




\begin{tabular}{|c|c|c|c|c|c|c|c|c|}
\hline \multicolumn{9}{|c|}{$\begin{array}{l}\text { Percent annual exceedance probability of 7-day flood-duration streamflow } \\
\text { (cubic feet per second) }\end{array}$} \\
\hline NRNI Site ID & 50-percent & 20-percent & 10-percent & 4-percent & 2-percent & 1-percent & 0.5 -percent & 0.2 -percent \\
\hline ALB & 68,100 & 94,800 & 113,000 & 137,000 & 155,000 & 174,000 & 193,000 & 219,000 \\
\hline BCL & 9,500 & 13,200 & 15,700 & 18,800 & 21,100 & 23,400 & 25,800 & 28,900 \\
\hline BLU & 2,680 & 3,710 & 4,360 & 5,140 & 5,690 & 6,230 & 6,760 & 7,430 \\
\hline CGR & 3,510 & 4,990 & 6,030 & 7,430 & 8,520 & 9,650 & 10,800 & 12,500 \\
\hline COT & 1,620 & 2,330 & 2,770 & 3,310 & 3,680 & 4,040 & 4,380 & 4,820 \\
\hline DET & 9,500 & 13,200 & 15,700 & 18,800 & 21,100 & 23,400 & 25,800 & 28,900 \\
\hline DEX & 12,900 & 18,600 & 22,500 & 27,600 & 31,500 & 35,400 & 39,500 & 45,000 \\
\hline DOR & 4,400 & 6,130 & 7,290 & 8,770 & 9,880 & 11,000 & 12,100 & 13,700 \\
\hline FAL & 3,230 & 4,390 & 5,140 & 6,050 & 6,700 & 7,340 & 7,970 & 8,800 \\
\hline FOS & 14,100 & 18,900 & 22,200 & 26,400 & 29,700 & 33,000 & 36,500 & 41,200 \\
\hline FRN & 4,150 & 6,050 & 7,210 & 8,540 & 9,450 & 10,300 & 11,100 & 12,000 \\
\hline GOSO & 9,700 & 13,900 & 16,600 & 19,800 & 22,200 & 24,500 & 26,800 & 29,700 \\
\hline GPR & 8,810 & 11,900 & 14,000 & 16,700 & 18,700 & 20,800 & 22,900 & 25,800 \\
\hline HARO & 50,700 & 69,700 & 83,000 & 101,000 & 114,000 & 129,000 & 144,000 & 165,000 \\
\hline HCR & 4,890 & 7,240 & 8,930 & 11,200 & 13,000 & 14,900 & 17,000 & 19,800 \\
\hline JASO & 18,700 & 26,400 & 31,400 & 37,600 & 42,100 & 46,400 & 50,700 & 56,400 \\
\hline JFRO & 39,800 & 53,600 & 63,400 & 76,400 & 86,600 & 97,300 & 109,000 & 124,000 \\
\hline LOP & 12,900 & 18,600 & 22,500 & 27,600 & 31,500 & 35,400 & 39,500 & 45,000 \\
\hline MEHO & 15,800 & 21,700 & 25,400 & 29,800 & 33,000 & 36,000 & 38,900 & 42,600 \\
\hline MNRO & 6,080 & 8,790 & 10,500 & 12,500 & 13,900 & 15,200 & 16,400 & 18,000 \\
\hline SLM & 115,000 & 158,000 & 186,000 & 222,000 & 250,000 & 277,000 & 304,000 & 342,000 \\
\hline SVN & 155,000 & 211,000 & 249,000 & 296,000 & 331,000 & 367,000 & 403,000 & 451,000 \\
\hline VIDO & 13,800 & 18,800 & 22,200 & 26,400 & 29,600 & 32,800 & 36,000 & 40,300 \\
\hline WAV & 16,100 & 21,800 & 25,400 & 30,000 & 33,400 & 36,700 & 40,100 & 44,500 \\
\hline WCC & 174,000 & 237,000 & 279,000 & 332,000 & 371,000 & 411,000 & 451,000 & 506,000 \\
\hline WTLO & 15,800 & 21,000 & 24,600 & 29,200 & 32,700 & 36,300 & 40,000 & 45,100 \\
\hline
\end{tabular}




\begin{tabular}{|c|c|c|c|c|c|c|c|c|}
\hline \multicolumn{9}{|c|}{$\begin{array}{l}\text { Percent annual exceedance probability of 10-day flood-duration streamflow } \\
\text { (cubic feet per second) }\end{array}$} \\
\hline NRNI Site ID & 50-percent & 20-percent & 10-percent & 4-percent & 2-percent & 1-percent & 0.5 -percent & 0.2 -percent \\
\hline ALB & 59,600 & 82,300 & 97,100 & 116,000 & 129,000 & 143,000 & 156,000 & 174,000 \\
\hline BCL & 8,250 & 11,200 & 13,100 & 15,300 & 16,900 & 18,500 & 20,000 & 22,000 \\
\hline BLU & 2,250 & 3,050 & 3,550 & 4,150 & 4,580 & 4,990 & 5,390 & 5,910 \\
\hline CGR & 3,030 & 4,220 & 5,070 & 6,200 & 7,090 & 8,020 & 8,990 & 10,400 \\
\hline $\mathrm{COT}$ & 1,390 & 1,970 & 2,310 & 2,710 & 2,980 & 3,240 & 3,470 & 3,760 \\
\hline DET & 8,250 & 11,200 & 13,100 & 15,300 & 16,900 & 18,500 & 20,000 & 22,000 \\
\hline DEX & 11,000 & 15,600 & 18,800 & 22,900 & 26,000 & 29,200 & 32,500 & 37,000 \\
\hline DOR & 3,750 & 5,130 & 5,960 & 6,930 & 7,610 & 8,240 & 8,840 & 9,600 \\
\hline FAL & 2,720 & 3,650 & 4,250 & 4,990 & 5,520 & 6,040 & 6,560 & 7,250 \\
\hline FOS & 12,100 & 15,900 & 18,400 & 21,600 & 23,900 & 26,300 & 28,600 & 31,800 \\
\hline FRN & 3,550 & 5,080 & 6,030 & 7,150 & 7,930 & 8,670 & 9,380 & 10,300 \\
\hline GOSO & 8,270 & 11,600 & 13,600 & 15,900 & 17,500 & 19,000 & 20,400 & 22,100 \\
\hline GPR & 7,600 & 10,100 & 11,600 & 13,500 & 14,800 & 16,000 & 17,300 & 18,800 \\
\hline HARO & 44,100 & 59,800 & 70,800 & 85,700 & 97,400 & 110,000 & 123,000 & 141,000 \\
\hline HCR & 4,180 & 6,080 & 7,430 & 9,230 & 10,600 & 12,100 & 13,600 & 15,700 \\
\hline JASO & 15,900 & 22,200 & 26,400 & 31,700 & 35,600 & 39,500 & 43,400 & 48,700 \\
\hline JFRO & 34,200 & 45,500 & 53,200 & 63,100 & 70,700 & 78,400 & 86,400 & 97,400 \\
\hline LOP & 11,000 & 15,600 & 18,800 & 22,900 & 26,000 & 29,200 & 32,500 & 37,000 \\
\hline MEHO & 13,600 & 18,300 & 21,100 & 24,500 & 26,800 & 29,100 & 31,200 & 33,900 \\
\hline MNRO & 5,210 & 7,400 & 8,780 & 10,400 & 11,600 & 12,800 & 13,900 & 15,300 \\
\hline SLM & 101,000 & 137,000 & 160,000 & 189,000 & 210,000 & 230,000 & 251,000 & 278,000 \\
\hline SVN & 138,000 & 185,000 & 215,000 & 253,000 & 280,000 & 307,000 & 334,000 & 370,000 \\
\hline VIDO & 12,100 & 16,200 & 19,000 & 22,400 & 25,000 & 27,600 & 30,300 & 33,900 \\
\hline WAV & 14,100 & 18,800 & 21,800 & 25,600 & 28,400 & 31,200 & 33,900 & 37,600 \\
\hline WCC & 154,000 & 207,000 & 241,000 & 283,000 & 314,000 & 344,000 & 375,000 & 415,000 \\
\hline WTLO & 13,600 & 17,800 & 20,500 & 23,900 & 26,500 & 29,000 & 31,600 & 35,000 \\
\hline
\end{tabular}




\begin{tabular}{|c|c|c|c|c|c|c|c|c|}
\hline \multicolumn{9}{|c|}{$\begin{array}{l}\text { Percent annual exceedance probability of 15-day flood-duration streamflow } \\
\text { (cubic feet per second) }\end{array}$} \\
\hline NRNI Site ID & 50-percent & 20-percent & 10-percent & 4-percent & 2-percent & 1-percent & 0.5 -percent & 0.2 -percent \\
\hline ALB & 51,000 & 69,300 & 80,600 & 94,100 & 104,000 & 113,000 & 121,000 & 133,000 \\
\hline BCL & 6,960 & 9,240 & 10,700 & 12,400 & 13,600 & 14,800 & 16,000 & 17,500 \\
\hline BLU & 1,840 & 2,470 & 2,860 & 3,330 & 3,670 & 3,990 & 4,300 & 4,700 \\
\hline CGR & 2,570 & 3,490 & 4,120 & 4,970 & 5,630 & 6,310 & 7,020 & 8,010 \\
\hline $\mathrm{COT}$ & 1,170 & 1,610 & 1,880 & 2,170 & 2,370 & 2,560 & 2,730 & 2,940 \\
\hline DET & 6,960 & 9,240 & 10,700 & 12,400 & 13,600 & 14,800 & 16,000 & 17,500 \\
\hline DEX & 9,260 & 12,700 & 15,200 & 18,500 & 21,100 & 23,900 & 26,800 & 30,900 \\
\hline DOR & 3,120 & 4,200 & 4,850 & 5,590 & 6,090 & 6,570 & 7,010 & 7,560 \\
\hline FAL & 2,280 & 3,010 & 3,470 & 4,030 & 4,430 & 4,830 & 5,220 & 5,730 \\
\hline FOS & 9,980 & 13,000 & 14,900 & 17,400 & 19,300 & 21,200 & 23,100 & 25,600 \\
\hline FRN & 2,970 & 4,160 & 4,870 & 5,670 & 6,210 & 6,710 & 7,160 & 7,720 \\
\hline GOSO & 6,850 & 9,420 & 11,000 & 12,700 & 13,900 & 15,000 & 16,100 & 17,400 \\
\hline GPR & 6,270 & 8,230 & 9,420 & 10,800 & 11,800 & 12,800 & 13,700 & 14,900 \\
\hline HARO & 37,700 & 50,200 & 58,700 & 69,800 & 78,200 & 86,900 & 95,900 & 108,000 \\
\hline HCR & 3,540 & 5,050 & 6,080 & 7,410 & 8,420 & 9,450 & 10,500 & 11,900 \\
\hline JASO & 13,500 & 18,500 & 21,700 & 25,600 & 28,500 & 31,300 & 34,100 & 37,800 \\
\hline JFRO & 28,600 & 37,200 & 43,000 & 50,500 & 56,100 & 61,800 & 67,600 & 75,600 \\
\hline LOP & 9,260 & 12,700 & 15,200 & 18,500 & 21,100 & 23,900 & 26,800 & 30,900 \\
\hline MEHO & 11,400 & 15,000 & 17,200 & 19,900 & 21,700 & 23,500 & 25,100 & 27,300 \\
\hline MNRO & 4,360 & 6,100 & 7,140 & 8,330 & 9,140 & 9,890 & 10,600 & 11,500 \\
\hline SLM & 86,000 & 115,000 & 133,000 & 154,000 & 170,000 & 185,000 & 199,000 & 218,000 \\
\hline SVN & 118,000 & 156,000 & 179,000 & 207,000 & 227,000 & 247,000 & 266,000 & 291,000 \\
\hline VIDO & 10,400 & 13,700 & 15,800 & 18,400 & 20,400 & 22,300 & 24,200 & 26,800 \\
\hline WAV & 12,200 & 15,900 & 18,300 & 21,200 & 23,300 & 25,500 & 27,600 & 30,400 \\
\hline WCC & 132,000 & 174,000 & 200,000 & 232,000 & 255,000 & 277,000 & 298,000 & 326,000 \\
\hline WTLO & 11,300 & 14,500 & 16,600 & 19,200 & 21,100 & 23,000 & 25,000 & 27,600 \\
\hline
\end{tabular}




\begin{tabular}{|c|c|c|c|c|c|c|c|c|}
\hline \multicolumn{9}{|c|}{$\begin{array}{l}\text { Percent annual exceedance probability of 30-day flood-duration streamflow } \\
\text { (cubic feet per second) }\end{array}$} \\
\hline NRNI Site ID & 50-percent & 20-percent & 10-percent & 4-percent & 2-percent & 1-percent & 0.5 -percent & 0.2 -percent \\
\hline ALB & 40,800 & 54,000 & 61,500 & 70,000 & 75,600 & 80,700 & 85,400 & 91,100 \\
\hline BCL & 5,380 & 6,920 & 7,930 & 9,200 & 10,100 & 11,100 & 12,100 & 13,400 \\
\hline BLU & 1,410 & 1,880 & 2,150 & 2,480 & 2,700 & 2,910 & 3,110 & 3,360 \\
\hline CGR & 2,040 & 2,680 & 3,120 & 3,690 & 4,120 & 4,560 & 5,020 & 5,650 \\
\hline $\mathrm{COT}$ & 880 & 1,180 & 1,370 & 1,590 & 1,740 & 1,900 & 2,040 & 2,230 \\
\hline DET & 5,380 & 6,920 & 7,930 & 9,200 & 10,100 & 11,100 & 12,100 & 13,400 \\
\hline DEX & 7,430 & 9,990 & 11,600 & 13,600 & 15,000 & 16,500 & 17,800 & 19,700 \\
\hline DOR & 2,380 & 3,170 & 3,640 & 4,180 & 4,550 & 4,890 & 5,220 & 5,620 \\
\hline FAL & 1,770 & 2,310 & 2,640 & 3,040 & 3,320 & 3,580 & 3,840 & 4,170 \\
\hline FOS & 7,700 & 9,930 & 11,400 & 13,200 & 14,500 & 15,800 & 17,200 & 18,900 \\
\hline FRN & 2,200 & 3,000 & 3,480 & 4,030 & 4,410 & 4,760 & 5,090 & 5,510 \\
\hline GOSO & 5,250 & 7,020 & 8,070 & 9,290 & 10,100 & 10,900 & 11,600 & 12,600 \\
\hline GPR & 4,830 & 6,300 & 7,160 & 8,140 & 8,800 & 9,410 & 9,990 & 10,700 \\
\hline HARO & 30,200 & 39,700 & 45,600 & 52,700 & 57,700 & 62,600 & 67,300 & 73,500 \\
\hline $\mathrm{HCR}$ & 2,770 & 3,780 & 4,490 & 5,440 & 6,180 & 6,960 & 7,770 & 8,910 \\
\hline JASO & 10,500 & 14,100 & 16,500 & 19,600 & 21,900 & 24,200 & 26,500 & 29,700 \\
\hline JFRO & 22,400 & 28,800 & 32,700 & 37,500 & 41,000 & 44,300 & 47,600 & 51,900 \\
\hline LOP & 7,430 & 9,990 & 11,600 & 13,600 & 15,000 & 16,500 & 17,800 & 19,700 \\
\hline MEHO & 8,780 & 11,300 & 13,000 & 15,000 & 16,500 & 17,900 & 19,400 & 21,300 \\
\hline MNRO & 3,230 & 4,440 & 5,180 & 6,040 & 6,640 & 7,210 & 7,740 & 8,420 \\
\hline SLM & 68,000 & 88,000 & 101,000 & 117,000 & 128,000 & 140,000 & 151,000 & 167,000 \\
\hline SVN & 94,000 & 120,000 & 137,000 & 157,000 & 172,000 & 186,000 & 200,000 & 219,000 \\
\hline VIDO & 8,560 & 10,900 & 12,400 & 14,200 & 15,500 & 16,800 & 18,000 & 19,700 \\
\hline WAV & 9,920 & 12,600 & 14,400 & 16,400 & 17,900 & 19,300 & 20,700 & 22,500 \\
\hline WCC & 105,000 & 135,000 & 153,000 & 176,000 & 192,000 & 208,000 & 224,000 & 245,000 \\
\hline WTLO & 8,810 & 11,200 & 12,700 & 14,600 & 16,000 & 17,300 & 18,600 & 20,300 \\
\hline
\end{tabular}




\begin{tabular}{|c|c|c|c|c|c|c|c|c|}
\hline \multicolumn{9}{|c|}{$\begin{array}{l}\text { Percent annual exceedance probability of 60-day flood duration streamflow } \\
\text { (cubic feet per second) }\end{array}$} \\
\hline NRNI Site ID & 50-percent & 20-percent & 10-percent & 4-percent & 2-percent & 1-percent & 0.5 -percent & 0.2 -percent \\
\hline ALB & 32,800 & 43,100 & 49,100 & 55,900 & 60,500 & 64,800 & 68,800 & 73,700 \\
\hline BCL & 4,390 & 5,510 & 6,200 & 7,010 & 7,590 & 8,140 & 8,670 & 9,350 \\
\hline BLU & 1,100 & 1,430 & 1,640 & 1,890 & 2,060 & 2,230 & 2,400 & 2,620 \\
\hline CGR & 1,650 & 2,120 & 2,450 & 2,880 & 3,210 & 3,550 & 3,900 & 4,390 \\
\hline $\mathrm{COT}$ & 700 & 929 & 1,060 & 1,220 & 1,320 & 1,420 & 1,510 & 1,630 \\
\hline DET & 4,390 & 5,510 & 6,200 & 7,010 & 7,590 & 8,140 & 8,670 & 9,350 \\
\hline DEX & 5,970 & 7,880 & 9,160 & 10,800 & 12,000 & 13,200 & 14,500 & 16,200 \\
\hline DOR & 1,840 & 2,440 & 2,820 & 3,260 & 3,580 & 3,890 & 4,190 & 4,590 \\
\hline FAL & 1,390 & 1,810 & 2,070 & 2,400 & 2,640 & 2,870 & 3,100 & 3,400 \\
\hline FOS & 6,110 & 7,840 & 8,910 & 10,200 & 11,100 & 12,000 & 12,900 & 14,000 \\
\hline FRN & 1,700 & 2,300 & 2,670 & 3,090 & 3,380 & 3,650 & 3,900 & 4,220 \\
\hline GOSO & 4,110 & 5,470 & 6,270 & 7,210 & 7,840 & 8,440 & 9,010 & 9,720 \\
\hline GPR & 3,780 & 4,880 & 5,560 & 6,370 & 6,940 & 7,500 & 8,050 & 8,750 \\
\hline HARO & 24,400 & 31,900 & 36,500 & 42,100 & 46,000 & 49,800 & 53,600 & 58,400 \\
\hline HCR & 2,250 & 3,020 & 3,530 & 4,190 & 4,680 & 5,180 & 5,690 & 6,370 \\
\hline JASO & 8,450 & 11,200 & 13,100 & 15,500 & 17,300 & 19,100 & 21,000 & 23,500 \\
\hline JFRO & 17,900 & 22,900 & 25,900 & 29,400 & 31,900 & 34,300 & 36,600 & 39,500 \\
\hline LOP & 5,970 & 7,880 & 9,160 & 10,800 & 12,000 & 13,200 & 14,500 & 16,200 \\
\hline MEHO & 7,070 & 8,990 & 10,200 & 11,600 & 12,600 & 13,600 & 14,500 & 15,800 \\
\hline MNRO & 2,510 & 3,410 & 3,960 & 4,590 & 5,030 & 5,440 & 5,820 & 6,310 \\
\hline SLM & 55,100 & 71,700 & 81,300 & 92,200 & 99,600 & 107,000 & 113,000 & 121,000 \\
\hline SVN & 75,400 & 97,500 & 111,000 & 127,000 & 138,000 & 148,000 & 158,000 & 171,000 \\
\hline VIDO & 7,130 & 8,920 & 10,100 & 11,500 & 12,600 & 13,600 & 14,700 & 16,100 \\
\hline WAV & 8,220 & 10,300 & 11,700 & 13,400 & 14,600 & 15,900 & 17,100 & 18,800 \\
\hline WCC & 84,500 & 109,000 & 124,000 & 142,000 & 154,000 & 166,000 & 177,000 & 192,000 \\
\hline WTLO & 7,020 & 8,930 & 10,100 & 11,500 & 12,500 & 13,400 & 14,400 & 15,500 \\
\hline
\end{tabular}



Publishing support provided by the U.S. Geological Survey Science Publishing Network, Tacoma Publishing Service Center

For more information concerning the research in this report, contact the Director, Oregon Water Science Center

U.S. Geological Survey

2130 SW 5th Avenue

Portland, Oregon 97201

https://or.water.usgs.gov 
